\title{
Albumin-directed antibodies in diabetes: demonstration of human serum albumin-directed IgM autoantibodies
}

\author{
I. Gregor, N. Iberg, W. Berger and R. Flückiger \\ Departments of Research and Internal Medicine, University Clinics, Kantonsspital, Basel, Switzerland
}

\begin{abstract}
Summary. Sera of 406 individuals, 174 Type 1 (insulin-dependent) diabetic patients, 125 non-diabetic family members and 107 unrelated control subjects, were screened for the presence of antibodies against glycated albumin. In none of these sera could such antibodies be detected. However, antibodies directed towards monomeric, unmodified human serum albumin were detected in 13 sera. These albumin autoantibodies were of the IgM class, and occured in sera from nondiabetic persons $(0.9-1.6 \%)$ and with a five-fold higher frequency in
\end{abstract}

sera from diabetic patients $(5.2 \%)$. The presence of albumin antibodies was neither related to the presence of diabetic late complications, islet cell antibodies, HLA-status nor duration of diabetes. The albumin antibodies were also found in sera from persons carrying antibodies against mumps (17\%) or Epstein-Barr virus.

Key words: Albumin, autoantibodies, IgM, diabetes.
Covalent attachment of low molecular weight substances to proteins can induce formation of antibodies against these haptens. Such antibodies can cause clinically relevant complications. Examples of such substances are the penicillins or metabolites of phenacetin $[1,2]$. Increased nonenzymatic glycosylation (glycation) of proteins in diabetes mellitus has also been considered to induce antibody formation against their respective glycated form [3-6]. However, to date the only case where this mechanism has been demonstrated to occur is that for the antibody causing agglutination of M-positive non-enzymatically glycosylated human erythrocytes [3]. In all other instances the antibodies were directed towards glycated proteins in which the ketoamine structure was reduced by chemical means.

The finding that antibodies against reduced glycated proteins occur in diabetic and nondiabetic person alike [6], and the fact that an enzymatic reduction of the ketoamine in vivo has not been demonstrated, renders it unlikely that these antibodies are of significance in the pathogenesis of diabetic complications.

Albumin is a suitable protein for investigating whether antibodies against its naturally occuring nonreduced glycated form occur in vivo for enhanced glycation of albumin in diabetes [7] as well as glycation-induced conformational changes of this protein are well established [8]. Therefore, we investigated whether ex- cessive attachment of glucose to albumin in diabetic patients leads to the formation of autoantibodies against glycated albumin.

\section{Subjects and methods}

Sera were obtained from a total of 406 individuals, 174 Type 1 (insulin-dependent) diabetic patients treated at the outpatient clinics of the Kantonsspital Basel, and from their 125 first degree relatives. One hundred seven control sera were obtained from patients attending the clinics for reasons other than diabetes and from healthy blood donors.

Human albumin 'reinst' (ORHA, Behringwerke, Marburg, FRG) was used. Bovine serum albumin (BSA), fraction V, was from Fluka (Buchs, Switzerland) and other animal albumins, fraction $V$, were from Sigma (St. Louis, Mo, USA). Peroxidase conjugated goat-antihuman-Ig antibodies were obtained either from Sigma or Tago Inc. (Burlingame, Calif, USA). The nitrocellulose paper was obtained from L. Schleiffer AG (Zürich, Switzerland). All other chemicals were of commercial origin and of the highest purity available.

\section{Dot assay}

Proteins were dotted on nitrocellulose paper strips at a concentration of $1.25 \mathrm{mg} / \mathrm{ml}$ in Tris-buffered saline (TBS: $0.02 \mathrm{~mol} / 1$ Tris- $\mathrm{HCl}$, $0.15 \mathrm{~mol} / 1 \mathrm{NaCl}, 0.01 \%$ sodium azide, $\mathrm{pH} 7.5$ ). Two single successive microliters were applied per dot and air-dried. Human immunoglobulins (human plasma diluted 1:100 in TBS) were also dotted and 


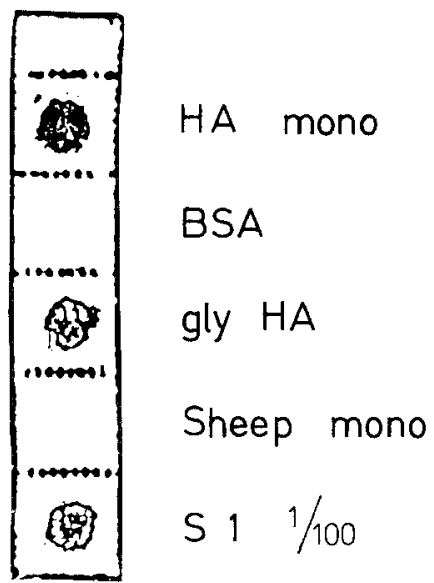

Fig. 1. Strip from dot-assay of a human albumin antibody positive serum (magnified). HA mono / sheep mono: monomeric human serum respectively sheep serum albumin; BSA: bovine serum albumin; gly HA: in vitro glycated monomeric human serum albumin; S1 1/100: human antibody serving as control of unimpaired dot assay

Table 1. Incidence of IgM albumin antibodies

\begin{tabular}{llll}
\hline Subject/condition & $n$ & Positive & Percentage \\
\hline Non-diabetic subjects & & & \\
$\quad$ Control & 107 & 1 & 0.9 \\
Family members of & 125 & $2^{\mathrm{a}}$ & 1.6 \\
$\quad$ diabetic patients & & & \\
Diabetic patient & 174 & $9^{\mathrm{a}, \mathrm{b}}$ & 5.2 \\
\hline
\end{tabular}

Non-diabetic subjects, seropositive for:

$\begin{array}{lrll}\text { Mumps (IgM) } & 12 & 2 & 17 \\ \text { Cytomegalo virus (IgM) } & 12 & 0 & 0 \\ \text { Epstein-Barr virus (IgG) } & 36 & 1 & 2.8 \\ \text { Rubella (IgG) } & 6 & 0 & 0 \\ \text { Herpes zoster (IgG) } & 5 & 0 & 0\end{array}$

a A non-diabetic family member found to be positive for albumin antibodies who developed diabetes during the study is excluded from the Table.

$b$ Two diabetic subjects were found seropositive for Hepatitis B surface/core antigens

Table 2. Genetic and immunologic characteristics of subjects positive for albumin antibodies

\begin{tabular}{|c|c|c|c|c|c|c|c|}
\hline \multirow{2}{*}{$\begin{array}{l}\text { Patient } \\
\text { initials }\end{array}$} & \multirow[t]{2}{*}{ Sex } & \multirow{2}{*}{$\begin{array}{l}\text { Duration } \\
\text { of diabetes } \\
\text { (years) }\end{array}$} & \multicolumn{4}{|l|}{ HLA } & \multirow[t]{2}{*}{$\mathrm{ICA}^{*}$} \\
\hline & & & A & B & $\mathrm{C}$ & $\mathrm{D}$ & \\
\hline MF & $\mathrm{m}$ & 2 & $\mathrm{nd}^{\mathrm{a}}$ & nd & nd & $7 /-$ & + \\
\hline PH & f & 31 & $1 / 2$ & $40 / 41$ & - & $-/ 6$ & - \\
\hline LL & f & 7 & $2 / 28$ & $15 / 44$ & $3 / 4$ & $1 / 4$ & + \\
\hline $\mathrm{AN}$ & $\mathrm{f}$ & 10 & $1 / 2$ & $15 / 7$ & - & $2 / 3$ & - \\
\hline $\mathrm{BA}$ & $\mathrm{m}$ & $>7$ & nd & nd & nd & nd & - \\
\hline RS & f & $>3$ & nd & nd & nd & nd & nd \\
\hline AA & $\mathrm{m}$ & 13 & 2 & $35 / 15$ & 0 & 4 & + \\
\hline WW & $\mathrm{m}$ & 3 & nd & nd & nd & nd & nd \\
\hline $\mathrm{CG}$ & $\mathrm{f}$ & 15 & $1 / 24$ & 8 & - & $3 / 4$ & - \\
\hline $\mathrm{CC}$ & $\mathrm{m}$ & nondiabetic & $2 / 11$ & $40 / 62$ & - & $3 / 4$ & - \\
\hline $\mathrm{AE}$ & $\mathrm{m}$ & nondiabetic & $2 / 3$ & $7 / 15$ & 3 & $2 / 4$ & + \\
\hline SF & $\mathrm{m}$ & 0.5 & $3 / 2$ & $7 / 8$ & - & 4 & $-1+$ \\
\hline
\end{tabular}

a nd: not determined

* ICA were determined and interpreted as described previously [9] served as a positive control of the assay. The strips were blocked by gentle agitation in 5\% bovine serum albumin in TBS for $15 \mathrm{~h}$ at room temperature. Subsequently each strip was incubated with $1 \mathrm{ml}$ of diluted serum (1:100 in 5\% BSA/TBS) for $5 \mathrm{~h}$ at room temperature. Diluted sera were then removed and the strips repeatedly washed with TBS for several hours. Peroxidase coupled antihuman antibodies (1:350 in TBS) were added and allowed to react for $4 \mathrm{~h}$. TBS washes were repeated and the peroxidase reaction initiated by the addition of developer mix (prepared by adding $0.6 \mathrm{ml}$ of the $0.3 \%$ chloronaphthol/methanol stock solution and $4 \mathrm{ul}$ of $30 \%$ hydrogen superoxide to $10 \mathrm{ml}$ TBS). A blue spot indicating a positive reaction became visible within $30 \mathrm{~min}$. (It was noted that reactivity against albumin gradually decreased in some of the sera stored at $-70^{\circ} \mathrm{C}$ over a one year period. This has to be considered in studies using quantitative instead of qualitative methodology.)

\section{Isolation of monomeric albumin}

All commercial albumins were passed over Sephacryl S-200 in $0.5 \mathrm{~mol} / \mathrm{l}$ ammonium acetate. Fractions containing monomeric albumin were pooled and lyophilized. Homogeneity of these fractions was assessed by SDS-PAGE and by HPLC gelfiltration. The high molecular weight fraction containing polymerized albumin was also collected and lyophilized.

\section{Preparation of glycated albumin}

Albumin $(50 \mathrm{mg} / \mathrm{ml})$ was incubated in $0.05 \mathrm{~mol} / 1$ phosphate buffer, $\mathrm{pH} 7.4$, in the presence of glucose $(50 \mathrm{mg} / \mathrm{ml})$ and sodium azide $(0.02 \%)$ for 10 days at $37^{\circ} \mathrm{C}$. Glycated albumin was isolated by affinity chromatography on Glycogel B $(10 \times 150 \mathrm{~mm})$ with $0.25 \mathrm{~mol} / \mathrm{l}$ ammonium acetate, $\mathrm{pH} 8.5$, as application buffer. For buffer exchange the glycated albumin was passed over Trisacryl GF-05. The albumin was applied and the unbound fraction washed out with application buffer at a flow rate of $30 \mathrm{ml} / \mathrm{h}$. Glycated albumin was eluted with $2 \times 5 \mathrm{ml}$ $0.2 \mathrm{~mol} / \mathrm{l}$ sorbitol in the application buffer. Glycated albumin was subjected to gelfiltration on Sephacryl S-200 as above and lyophilized.

\section{Statistical analysis}

The significance of the difference in the frequencies of occurence of albumin autoantibodies was evaluated by Fisher's exact test.

\section{Results}

Applying the dot assay to sera of 406 persons, we found albumin directed antibodies in 13 cases. A typical result of a positive dot assay is shown in Figure 1. These antibodies reacted comparably well with isolated glycated monomeric albumin and with the purified monomeric, dimeric and polymeric albumin fractions. Therefore, these antibodies were not specifically directed against glycated albumin. The albumin autoantibodies were detected in sera from diabetic patients as well as from control subjects, but the frequency of their occurence was five-fold higher in the diabetic patients $(p=0.0347)$ than in the nondiabetic control subjects (Table 1).

Although we failed to find autoantibodies specific against glycated albumin, we detected autoantibodies 
against unmodified albumin. All the albumin antibodies detected were of the IgM class as evidenced by their reactivity with antihuman-IgM but not with antihuman-IgA, E or G. The antibodies reacted only with human albumin and showed no crossreactivity with sheep, rabbit, pig or bovine serum albumin. Reaction between dotted human albumin and albumin antibodies present in the sera could be blocked by preincubating the sera overnight with human albumin prior to dotassay. In the most reactive sera complete blocking could be achieved by preincubation of the 1:100 diluted sera with $10 \mathrm{mg} / \mathrm{ml}$ of albumin. The reaction between human albumin and human albumin antibodies was not blocked by preincubation with animal albumin up to the concentration of $25 \mathrm{mg} / \mathrm{ml}$.

The presence of albumin antibodies seems not to be related to diabetic complications, as none of eight diabetic patients showing severe late complications of diabetes carried albumin directed antibodies, and all albumin antibody positive individuals were free of such complications. Duration of diabetes could also not be associated with the presence of these albumin antibodies (Table 2).

The genetic (HLA) or immunologic (ICA) status seems, in addition, unrelated to the expression of albumin antibodies (Table 2). The HLA D $3 / 4$ and the islet cell antibody frequencies in the albumin antibody carrying subjects were comparable to those of the general local diabetic population [9].

The temporal relationship between the appearance of albumin directed antibodies and islet cell antibodies was evaluated retrospectively. A tendency of the albumin antibodies to preceed occurence of the islet cell antibodies was noted. In 2 of our subjects (AE and SF) albumin antibodies were present before ICA occured. In all other instances, subjects either carried albumin antibodies only, or both albumin antibodies and ICA were present in all available samples. In this context it is of note that during the course of this study one of the nondiabetic albumin antibody positive individuals developed islet cell antibodies and then diabetes mellitus.

Because the appearance of islet cell antibodies is often connected with the destruction of $\mathrm{B}$ cells, and viral damage is considered to be a possible cause of this destruction [11], we also studied sera from persons seropositive for viral infections. Interestingly, the highest frequency of albumin antibodies was found in the sera containing mumps-virus-IgM antibodies (Table 1).

\section{Discussion}

The fact that we did not detect antibodies specific for glycated albumin in our experiments argues against the hypothesis that excessive attachment of glucose renders albumin antigenic. This finding may seem surprising in view of the reported occurence of glycation-induced an- tibodies against a new epitope in the case of the M-positive blood group antigen [3].

Glycation of proteins is a continuous and physiological process. In order to prevent excessive formation of autoantibodies by the haptene mechanism, autoantibodies may get formed only if a potentially antigenic region is modified. In glycated albumin the principal site of glucose attachement is Lys-525, an amino acid residue outside the antigenic regions of albumin [11].

The occurence of antibodies against albumin and the five-fold increased incidence of these IgM-albumin antibodies in a diabetic population is striking (Table 1). These antibodies with specificity toward native monomeric albumin and consequently also reacting with polymerized albumin, are different from the antibodies directed specifically towards polymerized albumin. The latter ones found in patients having hepatitis or otherwise affected livers [12] lack the reactivity towards monomeric albumin of the albumin antibodies described in this paper.

Albumin antibody expression seems to be a specific event and not an accompanying phenomenon to another autoimmune process. Five diabetic patients with high titres of both nuclear antibodies and thyroid antibodies, and 20 patients with thyroid disease and known titres of antibodies against various cell constituents studied, carried no albumin antibodies.

It remains to be established why albumin as an endogenous substance ordinarily in contact with the immune system becomes antigenic. It is known that an association between albumin and a viral protein occurs during infection with the hepatitis B virus [13]. A mechanism through which albumin could become antigenic might therefore consist of its association with an otherwise antigenic region, provided e. g. by a viral particle.

If this hypothesis explaining how viral damage to $B$ cells renders albumin antigenic proves valid, albumin antibodies would represent a marker of a viral etiology of diabetes mellitus.

Acknowledgements. The authors thank T. Woodtli for his skilful technical assistance and Dr. R. Berger, Professor P.Erb, and Professor J.J.Staub for providing the sera containing viral and thyroid antibodies respectively. This work was supported by grant No.3.260-0.82 from the Swiss National Science Foundation and by a grant from the Johnson Foundation.

\section{References}

1. Schneider CH, De Weck AL (1965) A new aspect of penicillin allergy: the direct reaction of penicillin with epsilon-amino groups. Nature 208: 57-59

2. Erne PE, Geczy AF, Spengler H, De Weck AL, Dubach UC (1977) Immunogenicity of p-phenetidine, 2-hydroxy-p-phenetidine and their protein conjugates in guinea pigs, rabbits and man. Int Arch Allergy Appl Immunol 53:319-328

3. Reid ME, Ellisor SS, Barker JM, Lewis T, Avoy DR (1981) Characteristics of an antibody causing agglutination of M-positive non-enzymatically glycosylated human red cells. Vox Sang 41: $85-90$ 
4. Witztum JL, Steinbrecher UP, Fisher M, Kesaniemi A (1983) Nonenzymatic glucosylation of homologous low density lipoprotein and albumin renders them immunogenic in the guinea pig. Proc Natl Acad Sci 80: 2757-2761

5. Bassiouny AR, Rosenberg H, McDonald TL (1983) Glucosylated collagen is antigenic. Diabetes 32:1182-1184

6. Nakayama H, Taneda S, Aoki S, Komori K, Kuroda K, Misawa K, Tsushima S, Nakagawa S (1985) Antibodies to nonenzymatically glucosylated albumin in the human serum. Biochem Biophys Res Commun 131: 720-725

7. Day JF, Thorpe SR, Baynes JW (1979) Nonenzymatically glucosylated albumin. J Biol Chem 254: 595-597

8. Shaklai N, Garlick RL, Bunn HF (1984) Nonenzymatic glycosylation of human serum albumin alters its conformation and function. J Biol Chem 259: 3812-3817

9. Spinas GA, Keller U, Neri TM, Matter L, Staffelbach O, Berger W (1985) HLA-Antigene und Inselzellantikörper bei Typ-1 Diabetikern verschiedener Altersgruppen und ihren Verwandten 1. Grades. Schweiz Med Wochenschr 115: 48-54

10. Craighead JE (1975) The role of viruses in the pathogenesis of pancreatic disease and diabetes mellitus. Prog Med Virol 19: $161-214$
11. Sakata S, Zouhair A (1980) Immunochemistry of serum albumin. $X$. Five major antigenic sites of human serum albumin are extrapolated from bovine albumin and confirmed by synthetic peptides. Mol Immunol 17: 139-142

12. Lenkei R, Mota G, Dan M-E, Laky M (1974) The polymerized albumin and antialbumin autoantibodies in patients with hepatic diseases. Rev Rom Biochim 11: 271-276

13. Pontisso P, Alberti A, Bortolotti F, Realdi G (1983) Virus-associated receptors for polymerized human serum albumin in acute and chronic hepatitis B virus infection. Gastroenterology $84: 220-226$

Received: 21 March 1986

and in revised form: 9 June 1986

Dr. R. Flückiger

Zentrum für Lehre und Forschung

Diabetologie

Hebelstrasse 20

CH-4031 Basel

Switzerland 